\title{
Seismic Performances of High Rise R/C Frame Structures Reinforced with High Strength Rebars
}

\author{
Adi Mulya Sanjaya ", Iswandi Imran* \\ ${ }^{\#}$ Department of Civil Engineering, Parahyangan Catholic University, Bandung-40141, Indonesia \\ E-mail: adimulyasanjaya@gmail.com \\ *Faculty of Civil Environmental Engineering, Bandung Institute of Technology, Bandung-40132, Indonesia \\ E-mail: iswandiimran@gmail.com
}

\begin{abstract}
Construction of high rise buildings as supporting infrastructures for economic growth has increased significantly in numbers in many big cities around the world. In Indonesia, most of the high-rise buildings constructed are made of reinforced concrete structures. In principles, the use of high-strength concrete, coupled with high strength rebars for high rise r/c buildings will result in more efficient and more constructible r/c constructions. However, in Indonesia, the use of high strength rebars for seismicresistant r/c buildings is still prohibited. SNI 2847:2013 Section 21 specifies that the yield strength for reinforcing bars used in structural elements of special moment resisting frames is limited to $420 \mathrm{MPa}$. This provision is meant to limit higher shear and higher bond demand in the structural elements assigned to dissipate seismic energy. This paper presents a study on the use of high strength rebars in seismic resistant $\mathbf{r} / \mathrm{c}$ buildings. In the study, 20 story buildings located in a region with high seismicity are designed. Two types of rebars are used, i.e., those with the yield strength of $550 \mathrm{MPa}$ and of $690 \mathrm{MPa}$. The building structures are designed as the special moment resisting frame. The seismic performances of the buildings are then investigated by performing non-linear time history analysis. Seven pairs of scaled ground motions are used for the analysis. From this analysis, the failure mechanism of r/c buildings reinforced with $550 \mathrm{MPa}$ yield strength is governed by beam mechanism, while the buildings reinforced with $690 \mathrm{MPa}$ yield strength rebars shows failure mechanism dominated by story mechanism. Globally, the performance levels of the buildings are within the zone of Damage Control (i.e., between immediate occupancy and life safety). Based on the findings, some recommendations are proposed for the use of high strength rebars in the design of seismic resistant high rise r/c buildings.
\end{abstract}

Keywords — ductility; non-linear time history analysis; performance-based design; high strength rebars

\section{INTRODUCTION}

The increase of quality of a product will always develop according to the needs and interest of modern era. The mobility of development in the technology of construction material gives an opportunity to provide more effective and efficient infrastructure to answer the human activity that is getting complex. One of measurement of the developing infrastructure is the ability in bearing heavier workload. This is in alignment with the innovation of construction material power that is being used.

The needs for a higher strength of concrete and steel reinforcement bar materials will be the main challenge in the development of the study in the construction of material technology. In principles, the use of high-strength concrete, coupled with high strength rebars for high rise r/c buildings will result in more efficient and more constructive r/c constructions.

However, in Indonesia, the use of high strength rebars for seismic-resistant $\mathrm{r} / \mathrm{c}$ buildings is still prohibited. SNI
2847:2013 Section 21 specifies that the yield strength for reinforcing bars used in structural elements of special moment resisting frames is limited to $420 \mathrm{MPa}$. This provision is meant to limit higher shear and higher bond demand in the structural elements assigned to dissipate seismic energy.

Deformed non-prestressed longitudinal reinforcement resisting earthquake-induced moment, axial force, or both, in special moment frames, special structural walls, and all components of special structural walls shall be in accordance with [9]:

1. Actual yield strength based on mill test does not exceed $f_{y}$ by more than $125 \mathrm{MPa}$. (Overstrength Ratio Factor).

2. The ratio of actual tensile strength to the actual yield strength is at least 1.25 (Ultimate Strength Ratio Factor).

If the parameters of rebar do not exceed from that provision, it means that the rebar has enough ductility to be 
used in dissipation energy caused by the cyclic load of the high rise $\mathrm{r} / \mathrm{c}$ building.

The security and performance level of the high-rise building structure in receiving applied load is essential considering of the location that is among crowded civilians. This study will elaborate the impact of using grade $550 \mathrm{MPa}$ and $690 \mathrm{MPa}$ steel reinforcement bar in the progress and seismic performance of high-rise $\mathrm{r} / \mathrm{c}$ building through Performance Base Design Analysis.

\section{MATERIAL AND METHOD}

The characteristic of concrete and rebar that are used in seismic high rise $\mathrm{r} / \mathrm{c}$ building will highly affect the yield mechanism of $\mathrm{r} / \mathrm{c}$ frame structure produced [1]. The parameters of rebar have to be in the provision of rules to prevent the failure of structure in inelastic phase caused by cyclic loading effect.

The rebar material in reinforcement concrete structure has a major role towards the yield mechanism of moment resistant frame structure. Ductility of rebars that is used has full responsibility in bearing force produced by reduction of base shear in the progress of design, especially for reinforced concrete structure building that designed with special rebar details. Some of the parameters in mechanical properties of rebar that affect plastic deformation of earthquake resistant r/c element structure [1], among others:

- The surface of the rebar (plain or thread) $\rightarrow$ affects bond strength between concrete and steel reinforcement bars materials.

- The tensile strength of rebar $\rightarrow$ influence the bond behavior that produced by $\mathrm{r} / \mathrm{c}$ element structure in inelastic condition.

- Overstrength ratio factor of rebar $\rightarrow$ that can affect yield mechanism hierarchy of $\mathrm{r} / \mathrm{c}$ structural building from post-elastic condition through the limits of the inelastic range.

- Ultimate Strength factor of rebar $\rightarrow$ affects the curvature ductility capacity of reinforced concrete sections.

- Total Elongation $\rightarrow$ influences the deviations and effective plastic hinges length of r/c structure elements.

The parameters of rebar mechanic behavior depend on the process of the product, starting from the method, composition of chemical elements that are used as the material, up to the goal of the rebar strength. In general, the high strength rebar material has lower ductility capacity than rebar with normal strength. The challenge of development in manufacturing rebar is producing high strength rebar with enough ductility for seismic-resistant reinforced concrete structure.

Commentary ACI 318-14, Section 20.2.2.4, said that for deformed reinforcement in special moment frames and special structural walls, the use of longitudinal reinforcement with strength substantially higher than assumed in Table 20.2.2.4a, ACI 318-14, will lead to higher shear and bond stresses at the time of development of yield moments. In that table, grade $550 \mathrm{MPa}$ steel reinforcement bar has to be an optional reinforcement that can be used for flexure, axial and lateral support for the special seismic system [9].

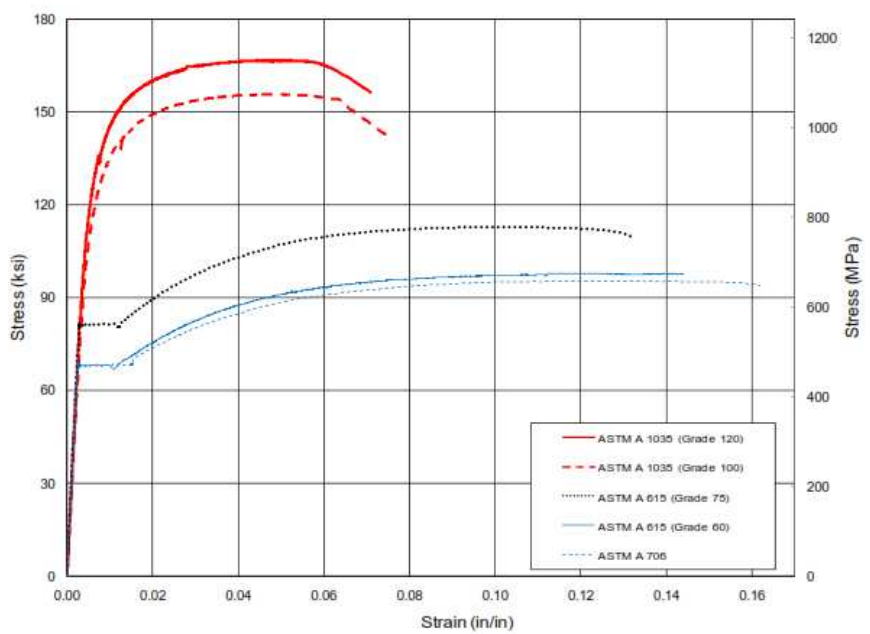

Fig. 1 Actual stress-strain curve for representative samples of various type and grades of ASTM steel reinforcing bars (WJE 2008)

Some ASTM (American Society for Testing and Materials) standard specification which set about the tensile requirements of reinforcement concrete bars to resist seismic load, these are ASTM A615/A615M, ASTM A706/A706M, dan ASTM A1035/A1035M. The various stress-strain relations curve of ASTM steel reinforcement bars is seen in Fig. 1.

\section{A. Material Properties}

The project of national research in Japan with the title development of Advanced R/C Building using High Strength Concrete and Reinforcement (new RC Project) has developed design criteria concrete material with compressive strength $30-120 \mathrm{MPa}$ and rebar material with yield strength $420-1200 \mathrm{MPa}$ as the construction material for high building earthquake resistant [6]. The achievement of a grade of concrete rebar that is the target research of New RC Project is divided into 4 zones, as shown in Fig. 2.

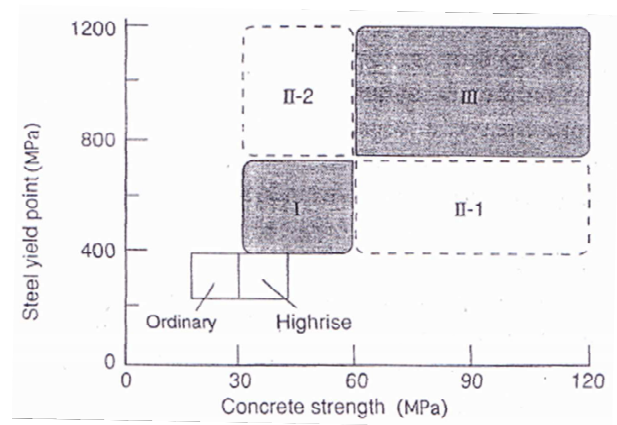

Fig. 2 Strength of materials and zone for New RC project research and development (Aoyama 2001)

Determining the strength concrete and rebar in this study is based on the classification of zone 1 from the New RC Project research. In using rebar with the strength of $400-$ $700 \mathrm{MPa}$ must be followed with concrete of $30-60 \mathrm{MPa}$. The application of high strength rebar in reinforcement concrete element that receives enough axial-cyclic load must be accompanied with high strength concrete which also compatible to hinder slip failure on the surface of bond strength between concrete and rebars.

1) Concrete Material: The compressive strength of concrete used in this study is $35 \mathrm{MPa}$ for horizontal structure 
element and 45MPa for the vertical. The ratio of horizontal and vertical compressive strength of concrete material should not be more than $1.4(45 \mathrm{MPa} / 35 \mathrm{MPa}=1.286)$. Stress-strain curve model of concrete material for confined and unconfined is using the formula in Kent and Park approach method [13] [20].

2) ASTM A706 Grade 550MPa Reinforcement: ASTM A706 steel is a deformed and plain low-alloy steel bar which has a well-controlled strength of the reinforcing steel. It is shown in the presence of specific requirements regarding not only minimum but also maximum yield stress as well as sustain larger elongations and meet specific chemical composition requirements [3]. ASTM A706 steel is routinely specified, at the minimum, for members expected to form plastic hinges.

The vast majority, approximately $98 \%$ of the ASTM A706 straight reinforcing bar actual stress-strain curves that were reviewed for this study have stress-strain relationships that include a linear-elastic portion with a well-defined or sharp yield point, followed by a yield plateau that eventually transitions to strain hardening (EPSH behavior) [3].

Specification ASTM A706 grade 550MPa reinforcement bar that is used in the study analysis are these.

- Yield strength $\left(f_{y}\right)$

$550 \mathrm{MPa}$

- Ultimate strength $\left(f_{u}\right)$

$690 \mathrm{MPa}$

- Modulus of Elasticity $\left(\mathrm{E}_{\mathrm{s}}\right)$ : $\quad 200000 \mathrm{MPa}$

- Total elongation $\left(\varepsilon_{\text {tot }}\right)$ : $10-12 \%$

The result data for material properties of ASTM A706 grade $550 \mathrm{MPa}$ reinforcement bar is taken from the experiment by Drit Sokoli as seen in Table 1.

The experiment shows that overstrength ratios factor of rebars are $\leq 1.3$ and ultimate strength ratios factor of rebars are $\geq 1.25$. The average of ASTM A706 grade 550MPa overstrength ratio factor from the experiment is in between of $1-1.046 \leq 1.25$. Thus, the overstrength ratio in the calculation of capacity design and the flexural strength of special column detail with this rebar still used 1.25. Total elongation from each specimen is also shown the result between 10 to $12 \%$.

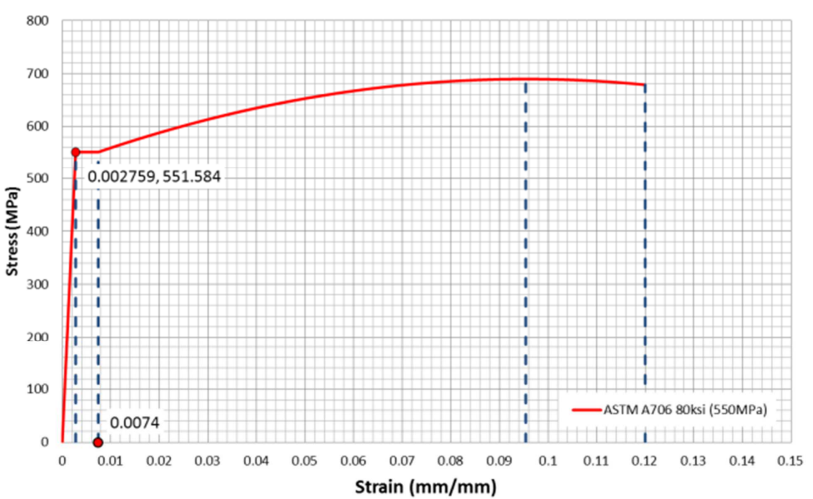

Fig. 3 Illustrating stress-strain EPSH relationship curve of ASTM A706 steel Re-bar grade $550 \mathrm{MPa}$

The approach of ASTM A706 grade steel stress-strain curve relations in Fig. 3 is obtained by using EPSH (ElasticPlastic curve with Strain Hardening) method from Charles Pankow Foundation [2] as seen below.

$$
\text { For } \varepsilon_{s}<\varepsilon_{y}, \quad f_{s}=E_{s} \varepsilon_{s}
$$

$$
\begin{gathered}
\text { For } \varepsilon_{y} \leq \varepsilon_{s} \leq \varepsilon_{s h}, \quad f_{s}=f_{y} \\
\text { For } \quad \varepsilon_{s h}<\varepsilon_{s} \leq \varepsilon_{t o t}, \\
f_{s}=f_{u}-\left(f_{u}-f_{y}\right)\left[\frac{\varepsilon_{s u}-\varepsilon_{s}}{\varepsilon_{s u}-\varepsilon_{s h}}\right]^{2}(\mathrm{psi})
\end{gathered}
$$

where is an ultimate tensile strain and $\varepsilon_{s h}$ is a strain of materials before the strain hardening happened. The recommendation value of both parameters to get ASTM A706 grade 550MPa EPSH curve are continuously 0.0954 dan 0.0074 [3]. For total elongation $\varepsilon_{\text {tot }}$ is taken according to specification, that is $12 \%$.

The cyclic test of rebar ASTM A706 has been done in the R/C column structure by Drit Sokoli, B.E. (2014), University of Texas, Austin. The specimens being used are CS60 and CS80, where both specimens are R/C column with identical flexure and shear strength. CS60 used the ASTM706 with grade $420 \mathrm{MPa}$, and CS80 used ASTM A706 with grade $550 \mathrm{MPa}$, both for the longitudinal and transversal specimens. Fig. 4 shows that the specimen of R/C column CS60 and CS80 has identical hysteretic curve and degradation characteristic. Both of the specimens have a stable cyclic performance with two amplitude cyclic load until it reaches drift ratio $>5.5 \%$.

The maximum drift ratio number produced by both specimens exceed the minimum performance objective for the area of collapse prevention in the level of Maximum Considered Earthquake (MCE) Hazard, which is 4\% [17].

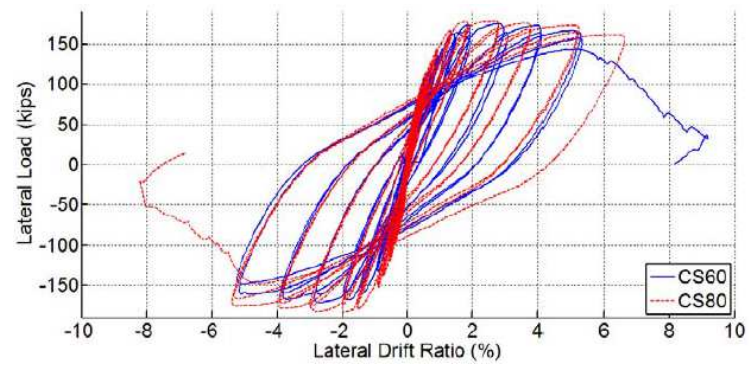

Fig. 4 Hysteresis response of CS60 and CS80 column specimen with ASTM A706 steel reinforcement bars (Drit Sokoli, B. E., University of Texas, 2014)

3) ASTM A1035 Grade 690MPa Reinforcement: ASTM A1035 steel is a type of steel which has low carbon level $(0.15 \%)$ and chrome $8-11 \%$. The high level of chrome in the contents caused the ASTM A1035 more resistant to corrosion compared to another type of steel. American concrete institute 's innovation task group 6 (ACI ITG-6) through Wiss, Janney, Elstner Associates, Inc. (WJE), conducted laboratory research to obtain the mechanical properties and the characteristic of steel refer to ASTM A1035.

The maximum actual yield strength of steel can be obtained by using $0.2 \%$ offset method or extension under load method $0.35 \%$. This is the consequence of high strength steel, where the yield strength does not appear obviously in the stress-strain curve tensile test result.

ACI ITG-6R-10, Design Guide for the use of ASTM A1035/1035M Grade 100 Steel Bars of Structural Concrete (ACI, 2010a), provides the recommendation of designing steps that need to be considered according to the use of high- 
strength steel ASTM 1035/1035M in members resisting earthquake effect. The design steps only apply to bars with

TABLE I

ASTM A706 Re-BARS TENSION Test Result GRADE 80KSI (550MPA) (DRIT SoKoli, B. E., University of TeXAs, 2014)

\begin{tabular}{|c|c|c|c|c|c|c|c|}
\hline \multirow{2}{*}{$\begin{array}{c}\text { Steel Re- } \\
\text { bars } \\
\text { Diameter } \\
(\mathrm{mm})\end{array}$} & \multirow[b]{2}{*}{$\begin{array}{l}\text { Specification } \\
\text { of Yield } \\
\text { Strength (ksi) }\end{array}$} & \multicolumn{4}{|c|}{ Test Result } & \multicolumn{2}{|c|}{ Ratio } \\
\hline & & $\begin{array}{c}\text { Yield } \\
\text { stress fya } \\
\text { (ksi) }\end{array}$ & $\begin{array}{l}\text { Fracture } \\
\text { Strength } \\
\text { fua (ksi) }\end{array}$ & \begin{tabular}{|c|} 
Uniform \\
Elongation \\
عsu (\%) \\
\end{tabular} & \begin{tabular}{|c|} 
Fracture \\
Elongation \\
etot (\%) \\
\end{tabular} & $\begin{array}{l}\text { Overstrength } \\
\text { Factor } \\
\text { (fya/fy) }\end{array}$ & $\begin{array}{c}\text { Ultimate } \\
\text { Strength Factor } \\
\text { ( fua / fya ) }\end{array}$ \\
\hline \multirow{4}{*}{$29(\# 9)$} & \multirow{4}{*}{80} & 78.8 & 106.2 & 8.735 & 14.1 & 0.985 & 1.348 \\
\hline & & 79.6 & 106.9 & 8.661 & N/A & 0.995 & 1.343 \\
\hline & & 79.1 & 106.8 & 8.992 & 17.6 & 0.989 & 1.350 \\
\hline & & 78.9 & 106.1 & 8.677 & 14.8 & 0.986 & 1.345 \\
\hline \multicolumn{2}{|c|}{ Average value } & 79.1 & 106.5 & 8.766 & 15.5 & 0.989 & 1.346 \\
\hline \multirow{3}{*}{$13(\# 4)$} & \multirow{3}{*}{80} & 84.3 & 110.9 & 8.705 & 11.8 & 1.054 & 1.316 \\
\hline & & 82.7 & 111.7 & 9.022 & 12.7 & 1.034 & 1.351 \\
\hline & & 84 & 111.8 & 8.828 & 12 & 1.050 & 1.331 \\
\hline \multicolumn{2}{|c|}{ Average value } & 83.667 & 111.467 & 8.852 & 12.167 & 1.046 & 1.332 \\
\hline
\end{tabular}

TABLE II

ASTM A1035 RE-BARS TENSION TEST RESUlt GRADE 100KSI (690MPA) (WJE, 2008)

\begin{tabular}{|c|c|c|c|c|c|c|c|}
\hline \multirow[b]{2}{*}{$\begin{array}{c}\text { Steel Re- } \\
\text { bars } \\
\text { Diameter } \\
(\mathrm{mm})\end{array}$} & \multirow[b]{2}{*}{$\begin{array}{c}\text { Specification } \\
\text { of Yield } \\
\text { Strength } f_{y} \\
\text { (ksi) }\end{array}$} & \multicolumn{4}{|c|}{ Test Result } & \multicolumn{2}{|c|}{ Ratio } \\
\hline & & $\begin{array}{c}\text { Stress } \\
\text { Corresponding } \\
\text { to EUL } 0.35 \% \\
\text { (ksi) }\end{array}$ & \begin{tabular}{|c|} 
Yield Strength \\
by Offset \\
$0.2 \%$ Method \\
$\mathrm{f}_{\mathrm{ya}}(\mathrm{ksi})$
\end{tabular} & $\begin{array}{c}\text { Tensile } \\
\text { Strength } \mathrm{f}_{\mathrm{ua}} \\
\text { (ksi) }\end{array}$ & $\begin{array}{c}\text { Total } \\
\text { Elongation } \\
\varepsilon_{\text {tot }}(\%)\end{array}$ & $\begin{array}{c}\text { Overstrength } \\
\text { Factor }\left(f_{\mathrm{ya}} / f_{\mathrm{y}}\right)\end{array}$ & $\begin{array}{l}\text { Ultimate Strength } \\
\text { Factor }\left(f_{\mathrm{ua}} / \mathrm{f}_{\mathrm{ya}}\right)\end{array}$ \\
\hline \multirow{3}{*}{36 (\#11) } & \multirow{3}{*}{100} & 99 & 129 & 159.7 & - & 1.29 & 1.238 \\
\hline & & 90 & 129 & 159.9 & 9.6 & 1.29 & 1.240 \\
\hline & & 94 & 131 & 159.9 & 8.5 & 1.31 & 1.221 \\
\hline \multicolumn{2}{|c|}{ Nilai rata-rata } & 94.3 & 129.7 & 159.8 & 9.1 & 1.297 & 1.233 \\
\hline \multirow{2}{*}{$25(\# 8)$} & \multirow{2}{*}{100} & 86 & 120 & 155.6 & 11 & 1.20 & 1.297 \\
\hline & & 93 & 122 & 155.2 & 10.2 & 1.22 & 1.272 \\
\hline \multicolumn{2}{|c|}{ Nilai rata-rata } & 89.500 & 121 & 155.4 & 10.6 & 1.21 & 1.284 \\
\hline
\end{tabular}

Specification ASTM A1035 grade 690MPa reinforcement bar that is used in the study analysis are these.

- Yield strength $\left(\mathrm{f}_{\mathrm{y}}\right)$

$690 \mathrm{MPa}$

- Tensile strength $\left(\mathrm{f}_{\mathrm{u}}\right)$

$1030 \mathrm{MPa}$

- Modulus of elasticity $\left(\mathrm{E}_{\mathrm{s}}\right)$ : $200000 \mathrm{MPa}$

- Total elongation $\left(\varepsilon_{\text {tot }}\right)$ : $6-7 \%$

The result data of ASTM A1035 grade 690MPa reinforcement bar is taken from the experiment by Wiss, Janney, Elstner Associates, Inc. (WJE) as seen in Table 2.

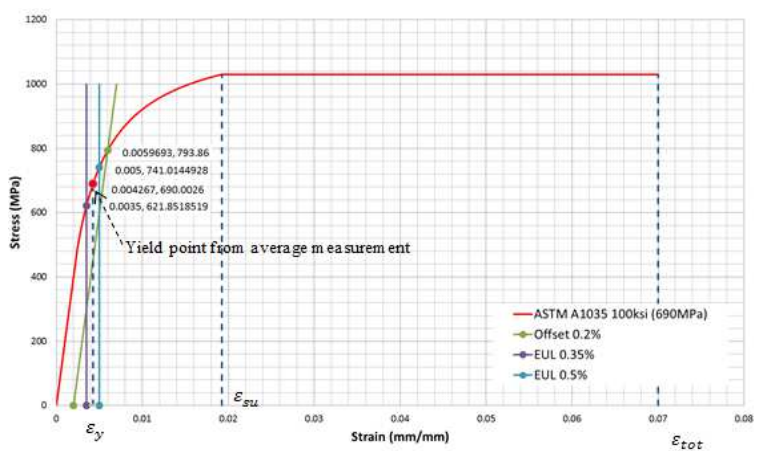

Fig. 5 Illustrating stress-strain RH relationship curve of ASTM A1035 steel Re-bar grade 690Mpa

The results of these experiments show that ASTM A1035 grade $690 \mathrm{MPa}$ rebar has overstrength ratio factor all of the specimens are $\leq 1.3$. However, the ultimate strength ratio of these rebars is $\geq 1.25$ only for rebar with diameter crosssection $25 \mathrm{~mm}$. The average of ASTM A1035 grade 690MPa overstrength ratio factor that resulted for rebars with diameter cross-section $25 \mathrm{~mm}$ is $\leq 1.25$ so that the overstrength ratio in the calculation of capacity design and the flexural strength of special column detail with this rebar still used 1.25.

From few numbers of overstrength and ultimate strength ratio factor from the specimen in Table 3 , grade $690 \mathrm{MPa}$ reinforcement bar that is used in structure element that is planned in dissipating seismic energy in this study is with $\leqslant$ $25 \mathrm{~mm}$ diameter rebar. The result of the experiment also shown that total elongation that exceeds the limit of ASTM A1035 grade $690 \mathrm{MPa}$ rebars is bigger than $7 \%$.

The approach of stress-strain relationship curve ASTM A1035 grade 690MPa rebar in Fig. 5 obtained by using the method equation of RH curve from Mast's Equation [14] followed by the limit of rebar tensile strength by ACI ITG$6 \mathrm{R}-10$ [8], where the numbers should not be bigger than the specification of tensile strength. This is equation curve that is used.

$$
\text { For } \varepsilon_{s}<0.0024, \quad f_{S}=E_{S} \varepsilon_{S}
$$

$$
\text { For } \quad 0.0024<\varepsilon_{S} \leq 0.02 \text {, }
$$




$$
\begin{gathered}
f_{s}=1170-\frac{2.96}{\varepsilon_{s}+0.0019} \quad(\mathrm{MPa}) \\
\text { For } 0.02<\varepsilon_{s} \leq \varepsilon_{\text {tot }}, \quad f_{s}=1030 \quad(\mathrm{MPa})
\end{gathered}
$$

For total elongation $\varepsilon_{t o t}$ is taken according to specification, that is $7 \%$.

TABLE III

DATA YIELD StRESS MEASUREMENT METHOd OF ASTM A1035 GRADE 690MPA REINFORCEMENT BAR

\begin{tabular}{|c|c|c|c|}
\hline No. & $\begin{array}{c}\text { Yield Strength } \\
\text { Approach Method }\end{array}$ & $\begin{array}{c}\text { Stress fs } \\
(\mathrm{MPa})\end{array}$ & Strain \&s (\%) \\
\hline 1 & EUL $0.35 \%$ & 621.852 & 0.35 \\
\hline 2 & EUL $0.5 \%$ & 741.014 & 0.50 \\
\hline 3 & Offset 0.2\% & 793.860 & 0.597 \\
\hline Stress average 1 dan 3: & $707.856 \mathrm{MPa}$ \\
$\begin{array}{c}\text { Stress average 1 dan 2: } \\
\text { Yield Strengh from average } \\
\text { measurement }\end{array}$ & $681.433 \mathrm{MPa}$ \\
\hline
\end{tabular}

From that equation, determination of yield strength rebar through approach method shows that yield strength from rebar stress-strain relations curve of ASTM A1035 grade $690 \mathrm{MPa}$ reinforcement bar has identical value with the specification, so the curve is considered applicable to represent the characteristic of mechanical properties of rebar in the analysis process of this study.

The research about the application of ASTM A1035 rebar was conducted by Jeffrey Michael Rautenberg at 2011. UC1.6-10 and UC-1.6-20 were 2 of 11 of the specimens of R/C column that is using ASTM A1035 120ksi (830MPa). All the parameter of the specimen are kept being similar, except for the axial compression load received by the specimens, each is 0.1 or $0.2 A_{g} f_{c}$.

From the hysteresis curve pada Fig. 6 and Fig. 7 it is shown that the specimen of the reinforced concrete column UC-1.6-10 with constant axial load $0.2 f_{c}{ }^{\prime} A_{g}$ has higher energy dissipation than the specimen of reinforced concrete UC-1.6-20 with constant axial load $0.1 f_{c}{ }^{\prime} A_{g}$. Drift ratio capacities that can be reached by both specimens is $5 \%$.

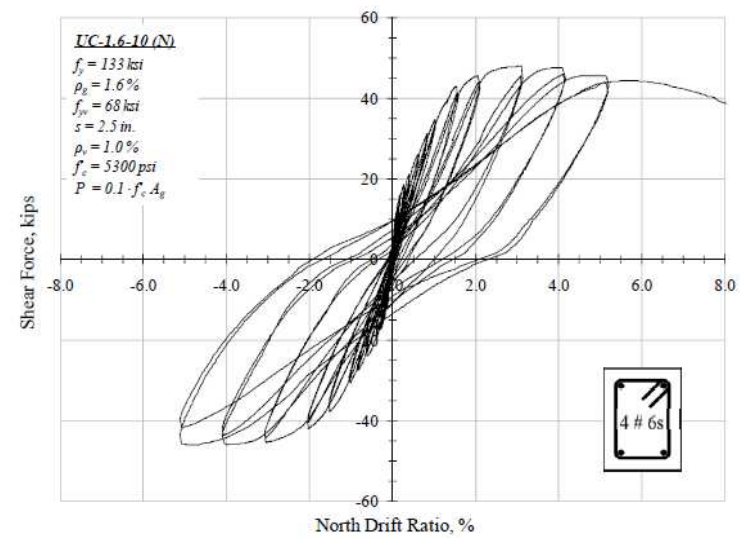

Fig. 6 Hysteresis response of UC-1.6-10 reinforced concrete column specimen (J. M. Rautenberg; 2011)

\section{B. Design and Detailing Consideration}

The structure of r/c apartment with a typical floor as shown in Fig. 8 is a three dimension typical model used to evaluate the influence of high strength rebar toward the performance of seismic resistant $\mathrm{r} / \mathrm{c}$ building structure. That structure has a seismic force-resisting system such as special reinforced concrete moment frames (open frame). The system of this building is designed according to some regulation that is valid in Indonesia, which are:

- For seismic load

SNI 1726:2012

- For gravity load

SNI 1727:2013

- R/C Building Structure

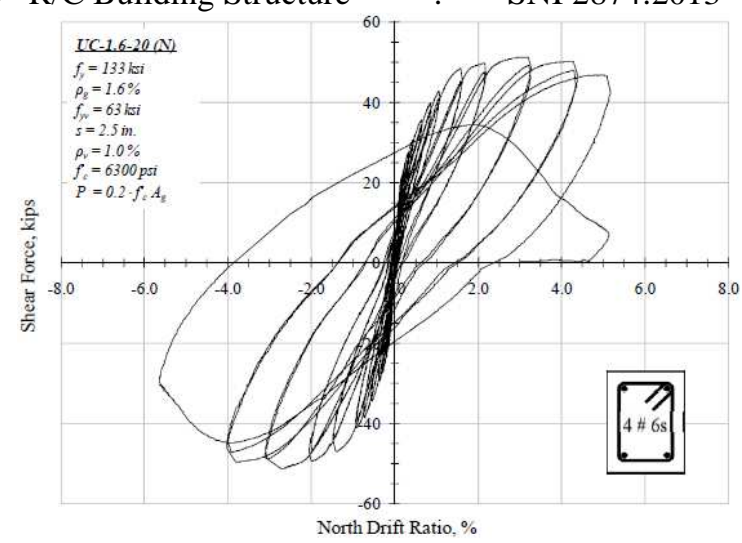

Fig. 7 Hysteresis Response of UC-1.6-20 Reinforced Concrete Column Specimen (J. M. Rautenberg; 2011)

The floor numbers of the building are 20, with two times adjustment of column cross-section properties, there are at 10 and 15 story. The height of the first floor is 5 meters, and the typical floor height is 4 meters.

1) Preliminary of Beam-Column Section: Determination of basic element dimension of the building structure obtained by going through preliminary design based on a survey of beam spans, load, and strength of the used material, according to SNI 2874:2013. Generally, typical economic beam spans for special moment frames are in the range 6 to 9 meters [15].

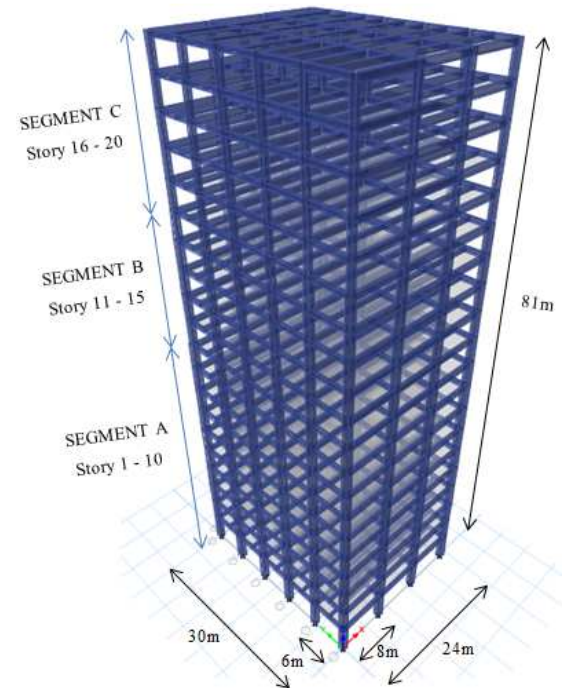

Fig. 8 Typical 3D models of 20 Story R/C apartment building structure

The application of rebar with bigger than grade $420 \mathrm{MPa}$ will affect preliminary of beam and column section properties. For structure element of $\mathrm{r} / \mathrm{c}$ beam with rebar strength $>420 \mathrm{MPa}$, the estimation of beam height obtained by the multiplication from minimum beam depth arranged in table 9.5(a), SNI 2847:2013, with enlargement factor seen below [22]. 


$$
\text { Enlargement factor } \quad=0.4+\frac{f_{y}}{700} \quad(\mathrm{MPa})
$$
of beam depth

The enlargement factor of beam depth has a goal to keep the bond strength of concrete to rebars in the flexural element structure sustainable so that it can give an optimum and stable performance.

For structural elements of reinforced concrete columns with special design, SNI 2847:2013 section 21.7.2.3 requires that where longitudinal beam reinforcement extends through a beam-column joint, the column dimension parallel to the beam reinforcement shall be at least 20 times the diameter of the largest longitudinal beam bar. The limit of number 20 is the bar diameter column depth ratio which is necessary for beam bar development. If the rebar grade bigger than $420 \mathrm{MPa}$, the comparison between the interior column dimensions to the rebar can be obtained to the equation of Hiroyuki Aoyama as seen below [6].

$$
h_{c}=\frac{1}{1.34\left(1+\frac{P u}{A_{g} f_{c^{\prime}}}\right)} \frac{f_{y}}{\left(f_{c^{\prime}}\right)^{2 / 3}} d_{b}(\mathrm{MPa})
$$

where $h_{c}$ is column depth, $P_{u}$ is ultimate axial load, $A_{g}$ is the cross-sectional area, $f_{c}$, is the compressive strength of the concrete material, and $d_{b}$ is the biggest of longitudinal beam bar diameter that is aligned with the column depth. The cross-sectional area needs to be obtained by the following equation [22].

$$
\begin{gathered}
P_{u}=0.8 \phi\left[0.85 f_{c}^{\prime} A_{g}\left(1-\rho_{s}\right)+f_{y} A_{s t}\right] \\
A_{g}=\frac{\frac{P_{u}}{0.8 \phi}}{0.85 f_{c}^{\prime}\left(1-\rho_{s}\right)+f_{y} \rho_{s}}
\end{gathered}
$$

where $\rho_{s}$ is ratio column longitudinal reinforcement bars. Anchorage of beam bars passing through an interior column depends on the column size. If the column section is sufficiently large, beam bar slip in the joint is small, and hence the hysteresis of members connected to the joint is stable with a large hysteretic area. According to equation 8 , the data in Table $\mathrm{V}$ shows that bar diameter column depth ratio is proportional to the increase of rebar strength that is being used. It means, the use of high-strength steel inevitably involve longer projected embedment length and larger column size [6].

2) Bar Buckling Resistant: SNI 2874:2013 regulation limits the spacing of transverse reinforcement in potential plastic hinges areas of beams and column and in boundary elements of walls to $6 \mathrm{~d}$ _b the diameter of the longitudinal bar. This requirement aims to restrain the longitudinal reinforcement and thus delays buckling when the reinforcement undergoes reverse cycles where yielding and hardening occurs in tension and compression in a plastic hinges area.

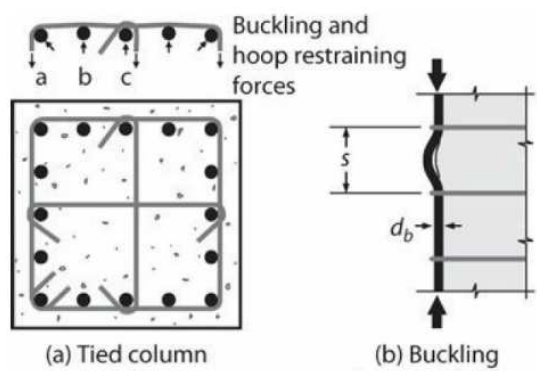

Fig. 9 Restraint of longitudinal bars and idealized buckling modes (Jack Moehole; 2014)

Dodd dan Restrepo-Posada, 1995, conducted analysis test of critical stress towards the compressive strength of rebars in grade $60 \mathrm{ksi}(420 \mathrm{MPa}), 80 \mathrm{ksi}(550 \mathrm{MPa})$, dan $100 \mathrm{ksi}$ $(690 \mathrm{MPa})$ with the ratio of $s / d_{b}$ as the parameter for each rebar grade.

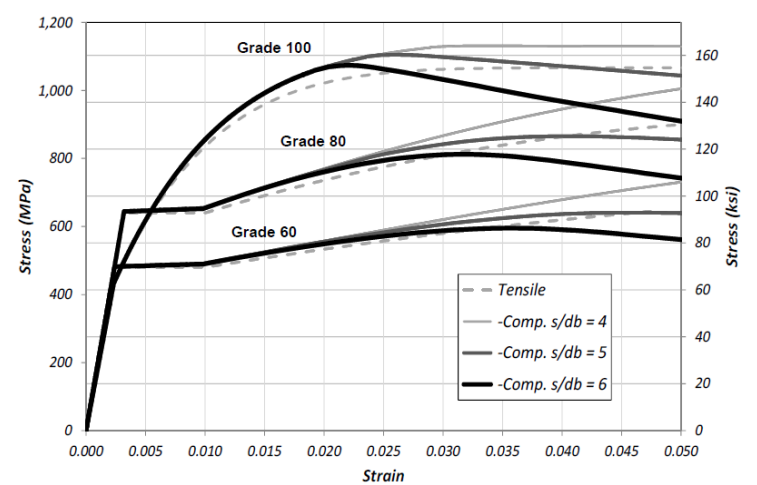

Fig. 10 Compressive Stress-Strain Response of Re-bars of Different Grade and Three $s / d_{b}$ Ratio (NIST GCR 14-917-30, NEHRP; 2014)

From Fig. 10, it can be seen that the compressive stressstrain responses of the grade $420 \mathrm{MPa}$ and grade $550 \mathrm{MPa}$ bars closely follow mirrored tensile stress-strain relationship up to a strain of approximately 0.025 for each $s / d_{b}$ ratio. Critical stress is a stress that happens when the phenomena of longitudinal bar buckling caused when the critical stress started to happen. This fact shows that the limits of spacing transverse reinforcement $6 d_{b}$ that is regulated in SNI 2874:2013 also applicable in longitudinal reinforcement bar with grade $550 \mathrm{MPa}$.

The compressive stress-strain responses of grade $100 \mathrm{ksi}$ $(690 \mathrm{MPa})$ with ratio $s / d_{b}=6$ shows lower critical strain. 0.025 critical strain achieve by the compressive stress-strain longitudinal bar with the grade over 550MPa, the limit of spacing transverse reinforcement has to be changed to $5 d_{b}$ [5].

3) Hysteresis Model Approach: The model of cyclic non-linear response is a method to predict the response characteristic of building structures in bearing the seismic load with various intensity in time history analysis. The goal of this method is to conduct a simulation in holistic deformation movement and deterioration of structure when it experiences post-elastic phase until the collapse caused by the applied load.

From many mechanisms of possible plasticity, the flexure mechanism in concrete reinforced is a plasticity mechanism dominated by the rebar that is being used. Plasticity behavior reinforced concrete will have enough ductility to sustain 
seismic load if the rebar has the specific limit according to the applied condition [1]. Some scientist conducted the experimental study of the cyclic reinforced concrete structure to obtain the property and yield mechanism of the specimen when it receives the cyclic load.

Even if it has different mechanical properties than ASTM A706 with the requirements material retaining burden cyclic, some researchers experimented in testing the properties and a mechanical characteristic of SAS 670 as reinforcement material against the cyclic load. Hooman Tavallali is one of the researchers that conducted the study of properties and characteristic of R/C column with the reinforcement of SAS 670 that receive the cyclic load. The element of CC4-X beam and UC4-X are 2 of 7 specimens that resulted in stable and well enough hysteresis curve.

UC4-X is a specimen that uses SAS670 with grade $670 \mathrm{MPa}$ as the material of $\mathrm{R} / \mathrm{C}$ column. And for $\mathrm{CC} 4-\mathrm{X}$ is the comparative specimen that is designed with grade $420 \mathrm{MPa}$ rebars. The hysteresis curve produced by both specimen of CC4-X and UC4-X shown in Fig. 11 has properties and characteristic that is slightly different. From the comparison between the hysteresis curve of the specimen $\mathrm{CC} 4-\mathrm{X}$ and UC4-X, it is seen that the reduction of the ratio of longitudinal rebar in increasing the steel strength will cause the post-cracking stiffness of the rebar decrease.

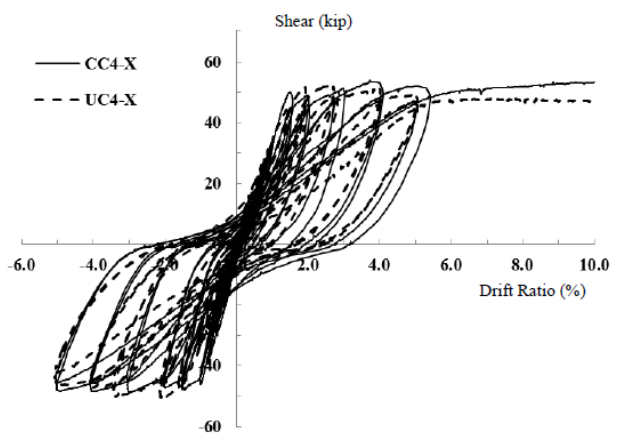

Fig. 11 Comparison of Measured Response, Specimens CC4-X and UC4X (H. Tavallali; 2011)

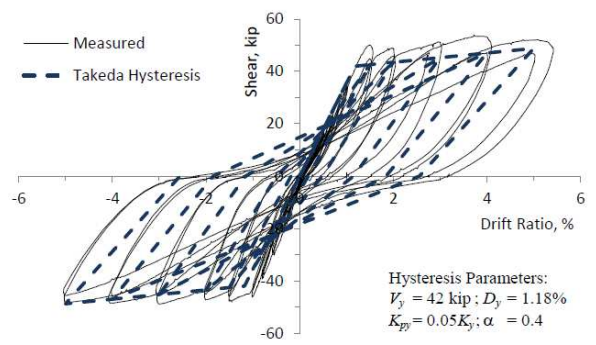

Fig. 12 Cyclic Response of Specimen CC4-X , Takeda Hysteresis Model and Measured Response (H. Tavallali; 2011)

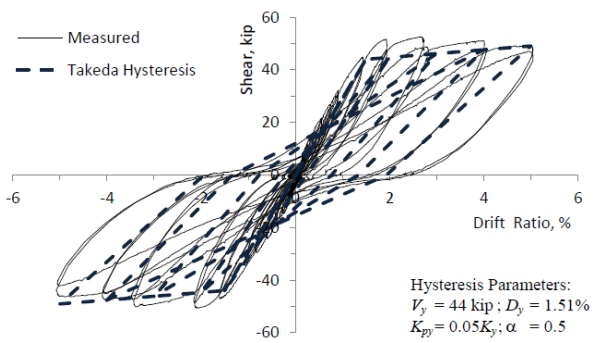

Fig. 13 Cyclic Response of Specimen UC4-X, Takeda Hysteresis Model and Measured Response (H. Tavallali; 2011)
Besides, the increase of steel strength also caused the deformation of the column structure when the rebar experience the yielding for the first time become bigger.

According to hysteresis response curve from H. Tavallali in Fig. 12 and Fig. 13, the approach model of the curve that is used to represent the mechanical properties and characteristic hysteresis curve of $\mathrm{r} / \mathrm{c}$ frame element building with high strength rebars in this study is using the response model with the type from Takeda Hysteresis.

\section{Seismic Analytical Design Model}

Hierarchy of the building collapse process can be obtained after do some a few analysis methods of the seismic-resistant building plan. Analysis of seismic load method that is used in this study is modal response spectrum analysis and inelastic dynamic non-linear time history analysis. Analysis and modeling of $\mathrm{r} / \mathrm{c}$ building structure are using ETABS 2016 v.16.0.2 program.

1) Load Combination: For ultimate load combination that is used in the modal response spectrum analysis is refer to SNI 1726:2012 sections 4.2.2. And for the combination of ultimate load use in inelastic dynamic non-linear time history analysis according to non-linear dynamic procedure ASCE/SEI 41-13 section 7.2.2

- $1.4 D$

- $1.2 D+1.6 L+0.5 L_{r}$

- $1.2 D+1.6 L_{r}+0.5 L$

- $\left(1.2+0.2 S_{D S}\right) D \pm 1.0 \rho Q_{E y} \pm 0.3 \rho Q_{E x}+0.5 L$

- $\left(1.2+0.2 S_{D S}\right) D \pm 1.0 \rho Q_{E y} \pm 0.3 \rho Q_{E x}+0.5 \mathrm{~L}$

- $\left(0.9-0.2 S_{D S}\right) D \pm 1.0 \rho Q_{E x} \pm 0.3 \rho Q_{E y}$

- $\left(0.9-0.2 S_{D S}\right) D \pm 1.0 \rho Q_{E y} \pm 0.3 \rho Q_{E x}$

- $Q_{G} \pm 1.0 E_{x} \pm 0.3 E_{y}$

- $Q_{G} \pm 1.0 E_{y} \pm 0.3 E_{x}$

where,

$$
Q_{G}=Q_{D}+Q_{L}+Q_{S}
$$

Combination load $\mathrm{a}-\mathrm{g}$ is used for modal response spectrum analysis, and the combination load $\mathrm{h}-\mathrm{i}$ is used for inelastic dynamic non-linear time history analysis.

For combination seismic load in inelastic dynamic nonlinear time history analysis, Guidelines for PerformanceBased Seismic Design of Tall Buildings (TBI), mention that application of ground motion acceleration as seismic load must use a pair of actual ground motion acceleration that works orthogonally in both main axes of the building.

2) Response Spectrum Analysis: The procedure of response spectrum analysis is done to control the movement of the fundamental natural period and obtaining the result of the elastic linear design of $\mathrm{r} / \mathrm{c}$ elements structure in receiving the response spectra acceleration of the planned design.

Response spectrum analysis has to include enough modes to obtain of combined mass participation factor at least $90 \%$ of the actual mass for each orthogonal horizontal direction reviewed by the model. Effective seismic weight calculated in modal response spectrum analysis is the whole dead load that works in building structures. Live load of the floor is not calculated for public garage floor and open-air parking structure, so it considered not giving contribution for an effective seismic weight of the building structure. 
Fig. 14 and Fig. 15 shows the dynamic movement of the structural model of building with rebar 550MPa and 690MPa mode shapes 3 degrees of freedom structure as follows: translation of $\mathrm{Y}$-axis, translation of $\mathrm{X}$-axis, and rotation of $\mathrm{Z}$-axis of the structure.

TABLE IV

TyPicAlly CRoss-SeCtion DimENSIONS OF R/C BEAm StRUCTURE ELEMENTS

\begin{tabular}{|c|c|c|c|c|c|c|c|}
\hline \multirow[b]{2}{*}{$\begin{array}{c}\text { Yield } \\
\text { Strength } \mathrm{f}_{\mathrm{y}} \\
(\mathrm{MPa})\end{array}$} & \multirow[b]{2}{*}{ Type of Beam } & \multicolumn{3}{|c|}{ Eksterior Beam } & \multicolumn{3}{|c|}{ Interior Beam } \\
\hline & & $\begin{array}{l}\text { Section } \\
\text { Name }\end{array}$ & $\begin{array}{c}\text { Beam } \\
\text { width } b_{b} \\
(\mathrm{~mm})\end{array}$ & $\begin{array}{c}\text { Beam } \\
\text { Height } \\
\mathrm{h}_{\mathrm{b}}(\mathrm{mm})\end{array}$ & $\begin{array}{l}\text { Section } \\
\text { Name }\end{array}$ & \begin{tabular}{|c|} 
Beam \\
width $b_{b}$ \\
$(\mathrm{~mm})$
\end{tabular} & $\begin{array}{c}\text { Beam } \\
\text { Height } \\
\mathrm{h}_{\mathrm{b}}(\mathrm{mm})\end{array}$ \\
\hline \multirow{3}{*}{550} & Balok Induk X & B48 & 400 & 800 & B48 & 400 & 800 \\
\hline & Balok Induk Y & B46 & 400 & 600 & B46 & 400 & 600 \\
\hline & Balok Anak & B36 & 300 & 600 & B36 & 300 & 600 \\
\hline \multirow{3}{*}{690} & Balok Induk X & B79A & 700 & 950 & B69A & 600 & 950 \\
\hline & Balok Induk Y & B57 & 500 & 700 & B47 & 400 & 700 \\
\hline & Balok Anak & B3A7 & 350 & 700 & B3A7 & 350 & 700 \\
\hline
\end{tabular}

TABLE V

TyPiCALly CRoss-SeCtion Dimensions of R/C COLUMN STRUCTURE ElEMENTS

\begin{tabular}{|c|c|c|c|c|c|c|c|c|}
\hline \multirow{2}{*}{$\begin{array}{l}\text { Conc. } \\
\text { Comp. } \\
\text { Strength } \\
\mathrm{f}_{\mathrm{c}}{ }^{\prime}(\mathrm{MPa})\end{array}$} & \multirow{2}{*}{$\begin{array}{c}\text { Re-bars } \\
\text { Yield } \\
\text { Strength } \\
\mathrm{f}_{\mathrm{y}} \text { (MPa) }\end{array}$} & \multirow{2}{*}{$\begin{array}{l}\text { Type of } \\
\text { Column }\end{array}$} & \multirow{2}{*}{$\frac{P_{u}}{A_{g} f_{c}}$} & \multirow{2}{*}{$\begin{array}{l}\mathrm{db} \max \\
(\mathrm{mm})\end{array}$} & \multirow[t]{2}{*}{$\mathrm{hc} / \mathrm{db}$} & \multicolumn{2}{|c|}{$\begin{array}{l}\text { Dimension Cross- } \\
\text { Section of Column }\end{array}$} & \multirow{2}{*}{$\begin{array}{c}\text { Section } \\
\text { Name }\end{array}$} \\
\hline & & & & & & $\mathrm{cx}(\mathrm{mm})$ & cy $(\mathrm{mm})$ & \\
\hline \multirow{6}{*}{45} & \multirow{3}{*}{550} & SegmentA & 0.617 & 32 & 23.723 & 900 & 900 & K99A \\
\hline & & SegmentB & 0.689 & 29 & 22.708 & 800 & 800 & K88B \\
\hline & & SegmentC & 0.693 & 25 & 22.654 & 650 & 650 & K6A6AC \\
\hline & \multirow{3}{*}{690} & SegmentA & 0.67 & 32 & 28.818 & 1000 & 1000 & K1010A \\
\hline & & SegmentB & 0.592 & 25 & 30.226 & 800 & 800 & K88B \\
\hline & & SegmentC & 0.658 & 22 & 29.017 & 700 & 700 & $\mathrm{~K} 77 \mathrm{C}$ \\
\hline
\end{tabular}

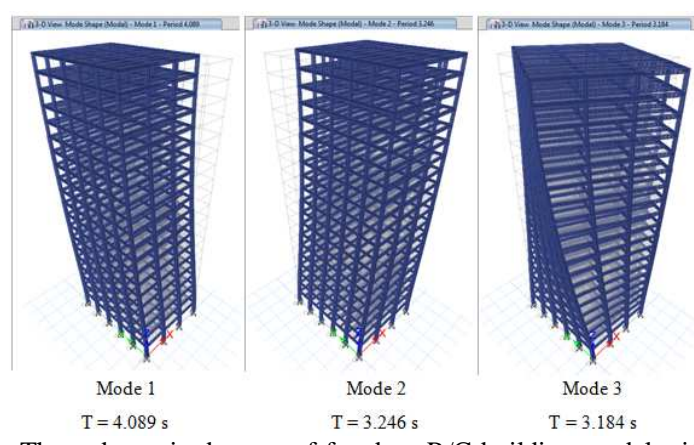

Fig. 14 Three dynamic degrees of freedom R/C building model with steel reinforcement bar grade $550 \mathrm{MPa}$

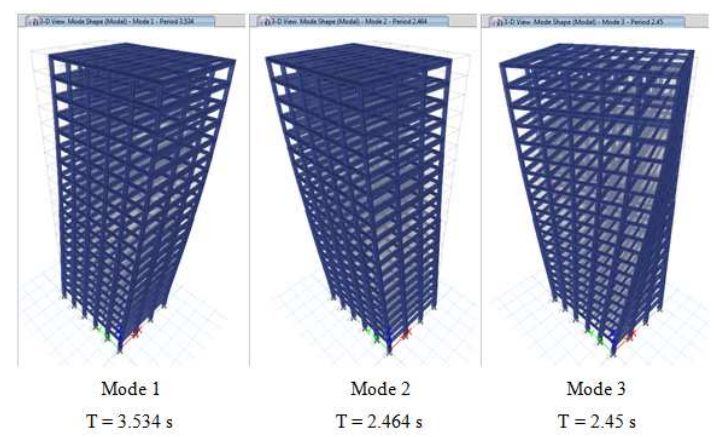

Fig. 15 Three dynamic degrees of freedom R/C building model with steel reinforcement bar grade $690 \mathrm{MPa}$

The amount of base shear seismic of the structure acquired based on the acceleration response of the design of above the ground seismic spectrum that acts as a function of the fundamental natural period structure. The generally fundamental natural period for building structure uniform building determined by mode shape which has the lowest frequency or can also be called as fundamental mode shape. For the building structure with reinforced concrete rebar of $550 \mathrm{MPa}$ and $690 \mathrm{MPa}$ has a fundamental natural period as follows 4.089 seconds and 3.534 seconds.

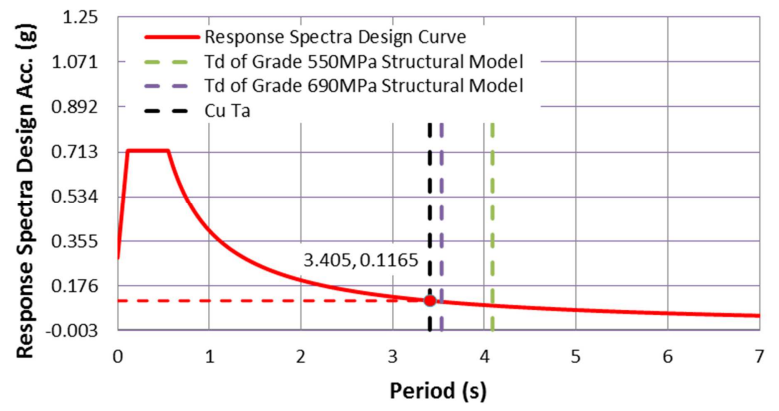

Fig. 16 Response spectrum design with an upper limit calculated period of grade $550 \mathrm{MPa}$ and $690 \mathrm{MPa} \mathrm{R} / \mathrm{C}$ building structure models

3) Earthquake Ground Motion: In an inelastic dynamic nonlinear time history analysis, the seismic loads that used are the actual ground acceleration from the location with similar geological, topographical, and seismic tectonic condition as the location of the actual building. The location of the building is in Denpasar, Bali, with intermediate ground classification. The SNI1726:2012 is giving limitation that at least three appropriate ground motion of acceleration must be used in inelastic dynamic nonlinear time history analysis. In this study, the inelastic dynamic nonlinear time history analysis is using a several recording of actual ground acceleration acquired from PEER Ground Motion Database (Pacific Earthquake Engineering Research Center). 
The recommended value of the ground acceleration magnitude for inelastic dynamic nonlinear time history analysis ranged between 4.9 - 7.9 SR. The average shear wave velocity in the depth of $30 \mathrm{~m}\left(\mathrm{v}_{\mathrm{s} .} 30\right)$ of actual ground acceleration is similar to the classification of the ground structure of the building. For intermediate ground classification, SNI 1726:2012 giving limitation for average shear wave velocity in the depth of $30 \mathrm{~m}$ ranged between 175 - $350 \mathrm{~m} / \mathrm{s}$. The distance range of the causative fault and the source of the earthquake from the actual ground acceleration should be adjusted with the condition of the causative fault and the source of the earthquake in Indonesian area which indeed dominated by the epicenter that came from causative fault on the sea area [25].

The ground motions which have been chosen to represent the ground motion of the building location reviewed must be scaled in a way so the average value of the spectrum response with 5\% dumping of all the ground motions cannot be less than the maximum acceleration seismic response spectrum $\mathrm{MCE}_{\mathrm{R}}$ on the surface of the ground for period of $0.2 \mathrm{~T}$ to $1.5 \mathrm{~T}$, in which $\mathrm{T}$ is natural structural period in variety of fundamental natural period to the direction of analyzed response.

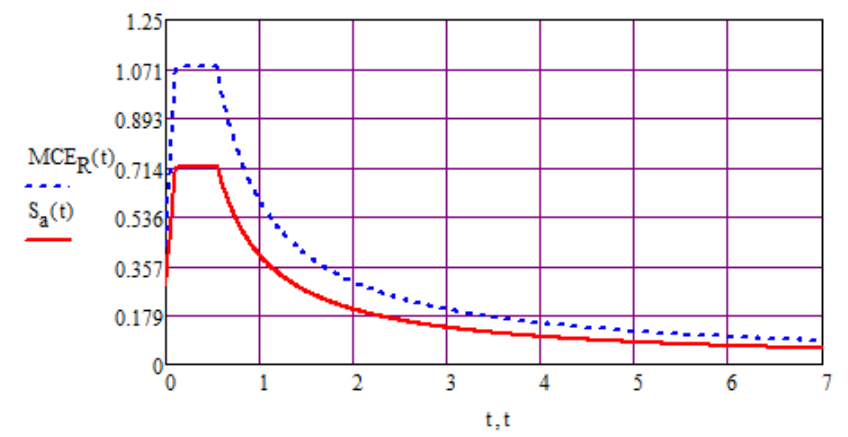

Fig. 17 MCER Response Spectrum at Stiff Soil Site Class, Denpasar, Bali

The scale of ground motion acceleration that is used for the inelastic dynamic nonlinear time history analysis on reinforced concrete building in this study is a scale with two dimension analysis (2D), wherein each pair of horizontal ground motion component only one with the biggest pseudospectra intensity is used.

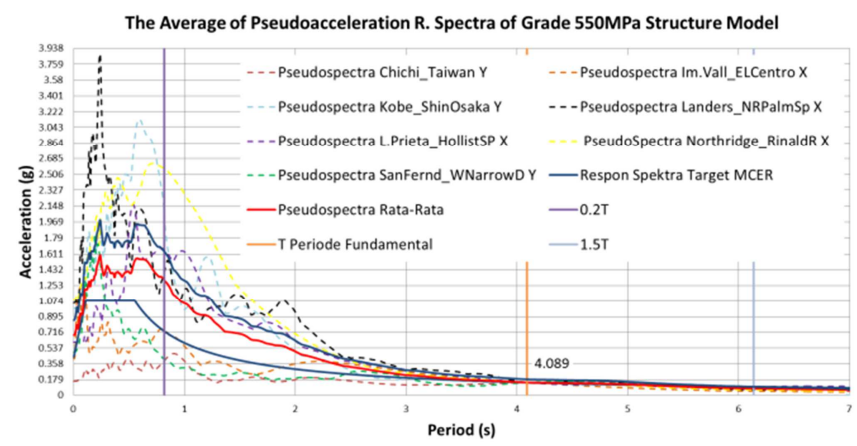

Fig. 18 The average of pseudo acceleration response spectra of the structure with grade 550MPa steel re-bars

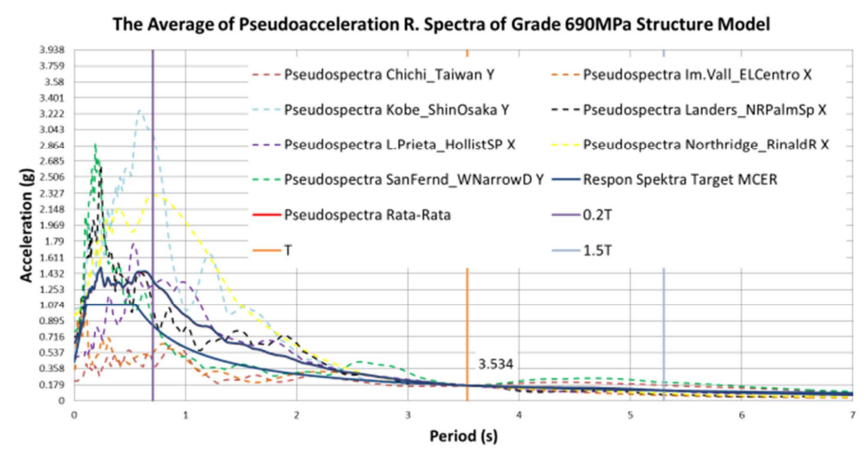

Fig. 19 The average of pseudo acceleration response spectra of the structure with grade 690MPa steel re-bars

The scaling method that is used in inelastic dynamic nonlinear time history analysis of the building follow the steps that are written in the Guide to the Seismic Load Provision of ASCE 7-10, by Finley A. Charney, Ph.D., P.E.

Every ground motion that is selected based on the biggest pseudo-spectra intensity from each pair of the actual ground motion components is used as the seismic load to both orthogonal directions of this building structure separately. The conversion of each actual ground motion into pseudospectra is using SeismoSignal program v. 2016.

4) Time History Analysis: SNI 1726:2013 regulation explains that inelastic dynamic nonlinear time history analysis procedure must contain mathematic analysis model of a structure which directly calculated the structure element of hysteresis response to determining the response through an integrated numeric method of a set of ground motion time history that compatible with spectrum response design for the previewed site. Nonlinear hysteresis behavior of the beam structural elements and reinforced concrete column is modeled through plastic hinge curve which obtained from moment-curvature analysis of the section using the Xtract v.3.0.8 program.

In this study integrated numeric method which used to complete the equation of differential nonlinear movement system of the building structure is a method Hilber-HughesTaylor (HTT alpha method). According to the FEMA 451, the circular frequency of the system mode shape movement of the structural system which used as a constant parameter of the proportional mass matrix and rigidity to produce $5 \%$ dumping from frequency mode shape 1 and 3 . 
TABLE VI

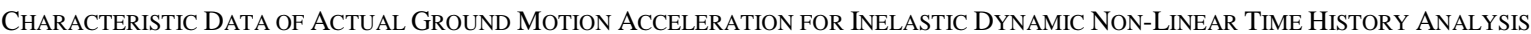

\begin{tabular}{|c|c|c|c|c|c|}
\hline No. & Earthquake Name & Station Name & Code Name & Magnitude & Vs30 (m/s) \\
\hline 1 & "Chi-Chi_Taiwan" & "CHY101" & Chichi_Taivan & 5.9 & 258.89 \\
\hline 2 & "Imperial Valley-06" & "E1 Centro Array \#6" & ImVall_ELCentro & 6.53 & 203.22 \\
\hline 3 & "Kobe_Japan" & "Shin-Osaka" & Kobe_ShinOsaka & 6.9 & 256 \\
\hline 4 & "Landers" & "North Palm Springs" & Landers_NRPalmSp & 7.28 & 344.67 \\
\hline 5 & "Loma Prieta" & "Hollister - South \& Pine" & LPriet__HollistSP & 6.93 & 282.14 \\
\hline 6 & "Northridge-01" & "Rinaldi Receiving Sta" & Northidge_RinaldR & 6.69 & 282.25 \\
\hline 7 & "SanFemando" & "Whittier Narrows Dam" & SanFernd_WNarrowD & 6.61 & 298.68 \\
\hline
\end{tabular}

\section{RESULT AND DISCUSSION}

\section{A. Hinges Properties}

Seismic performance building structure generally designed for a lower seismic load than spectra target. This is possible because the structure is design to experience damage or inelastic behavior through the construction of plasticity joint of the structure elements when it received design seismic load.

In nonlinear dynamic procedure (NDP) arranged in either FEMA 356 or ASCE/SEI 41-13, the capacity of plastic hinges shown by the relationship curved between bearing capacity (flexure or lateral) against deformation (rotation or displacement) which resulted in the structural element. Plastic hinge model uses elastoplastic (bilinear) curve where the yielding point used is significant yield moment coordinate point. The general curve of the model of the plastic hinge generally described through five important points $(\mathrm{A}, \mathrm{B}, \mathrm{C}, \mathrm{D}$, and $\mathrm{E})$ in according to the parameter arranged on the table 10-7 and 10-8 ASCE/SEI 41-13.

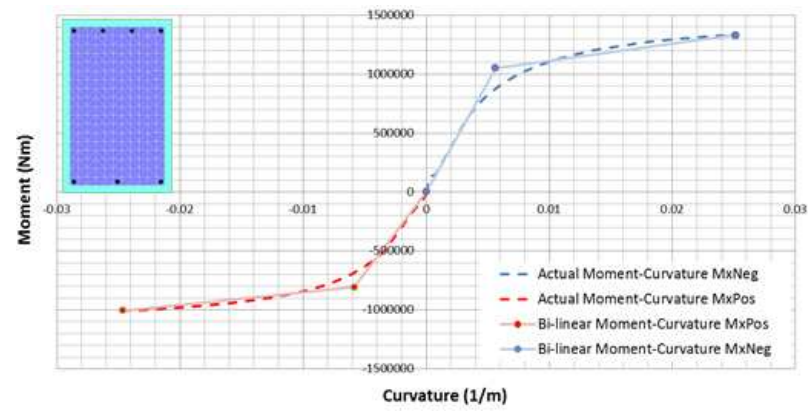

Fig. 20 Actual and bilinear moment-curvature relationship curve of B69A $\mathrm{R} / \mathrm{C}$ beam structure with grade $690 \mathrm{MPa}$ steel re-bar (Xtract v.3.0.8)

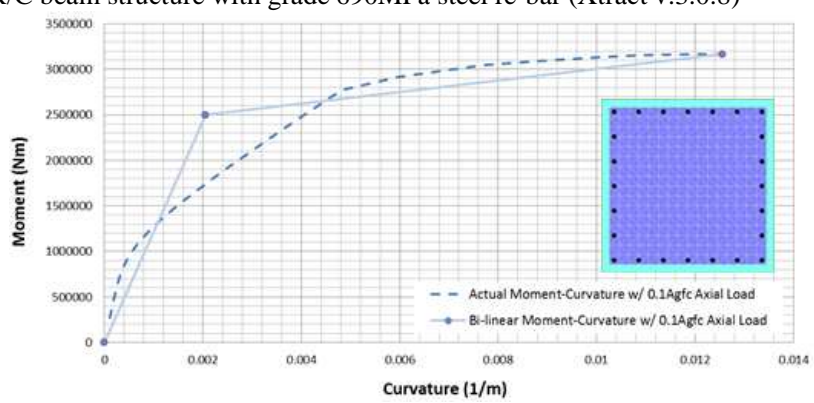

Fig. 21 Actual and bilinear moment-curvature relationship curve of K99A $\mathrm{R} / \mathrm{C}$ column structure with grade $550 \mathrm{MPa}$ steel re-bars caused by $\mathrm{X} / \mathrm{Y}$ flexural moment and $0.1 A_{g} f_{c}$ axial loads (Xtract v.3.0.8)
The parameter of the moment-rotation relationship curve model on the table can only be used if the strength of rebars in reinforcement concrete section is not more than $420 \mathrm{MPa}$. For the rebar with the strength more than 420MPa momentrotation correlation curve model is acquired from the conversion bilinear moment-curvature relationship curve for each structure section element based on Park and Paulay equation.

$$
\theta_{p}=\left(\varphi_{u}-\varphi_{y}\right) l_{p}
$$

where, $\varphi_{u}=$ Ultimate Curvature

$\varphi_{y}=$ Significant Yield Curvature

$l_{p}$ is plastic hinge length and can be obtained by the following equation.

$$
l_{p}=0.08 l+0.022 d_{b} f_{y}(\mathrm{MPa})
$$

$l$ is the length of the clear span.

\section{B. Component Performance}

1) Acceptance Criteria: Acceptance criteria of component performance arranged on the table 10-7 and 10-8 ASCE/SEI 41-13 only applicable to the reinforced concrete element structure with the rebar strength less than 420MPa.

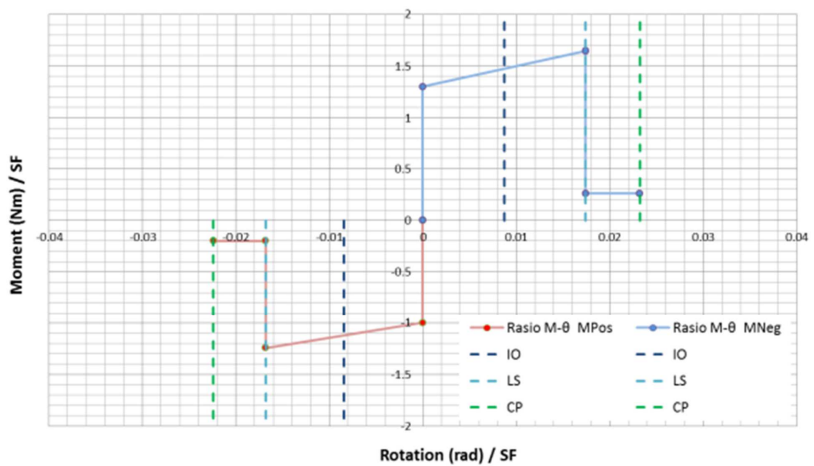

Fig. 22 Plastic rotation angle of B69A R/C beam structure with acceptance criteria of component performance level according to ASCE/SEI 41-13

Acceptance criteria of component performance determined based on moment-rotation relationship curve obtained from the result of an independent analysis that follows acceptance criteria regulation that arranged in ASCE 41-13 section 7.6.3. 
2) Assessment of Component Performance: The intensity of seismic load worked at a structure will be dissipated through an event of plastic hinge formation which occurred on the structural elements.

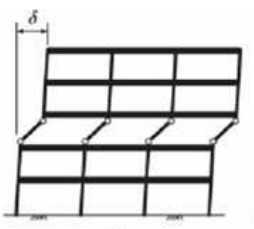

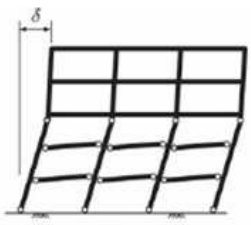

(b)

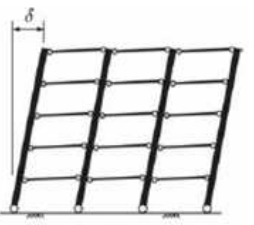

(c)
Story Mechanism Intermediate Mechanism Beam Mechanism

Fig. 23 Idealized yield mechanism of moment resisting frame (Jack Moehole; 2014)

The hierarchy of structural collapse caused by the intensity of strong seismic load which is an equation of time determined based on the sequence of the plastic hinges formation which happened on the structural system.

An ideal plastic mechanism of the building structure moment resisting frame system and which resulting in stable hysteresis behavior is a plastic mechanism of the beam's structural element (beam mechanism). In this mechanism, plastic hinge formed at the edge of beam structural element and on the base of the lowest column that meets with the foundation.

TABLE VII

REVIEW OF THE YieLd MEChANISM RESUlt OF R/C BUILDing STRUCTURE WITH GRADE 550MPA STEEL RE-BAR

\begin{tabular}{|c|c|c|c|c|c|}
\hline $\begin{array}{c}\text { Actual Ground Motion } \\
\text { Acceleration }\end{array}$ & $\begin{array}{c}\text { Direction } \\
\text { of Load }\end{array}$ & $\begin{array}{c}\alpha \text { HTT } \\
\text { coeffisient }\end{array}$ & $\begin{array}{c}\text { Convergence } \\
\text { Total Step }\end{array}$ & $\begin{array}{c}\text { Numbers } \\
\text { of Step } \\
\text { Target }\end{array}$ & Yield Mechanism \\
\hline \multirow{2}{*}{ "Chi-Chi_Taiwan" } & $\mathrm{X}$ & 0 & 800 & 800 & beam mechanism \\
\cline { 2 - 6 } & $\mathrm{Y}$ & 0 & 800 & 800 & beam mechanism \\
\hline \multirow{2}{*}{ "Imperial Valley-06" } & $\mathrm{X}$ & 0 & 350 & 350 & beam mechanism \\
\cline { 2 - 6 } & $\mathrm{Y}$ & 0 & 350 & 350 & beam mechanism \\
\hline \multirow{2}{*}{ "Kobe_Japan" } & $\mathrm{X}$ & 0 & 400 & 400 & story mechanism \\
\cline { 2 - 6 } & $\mathrm{Y}$ & 0 & 395 & 400 & story mechanism \\
\hline \multirow{2}{*}{ "Landers" } & $\mathrm{X}$ & 0 & 900 & 900 & beam mechanism \\
\cline { 2 - 7 } & $\mathrm{Y}$ & 0 & 900 & 900 & beam mechanism \\
\hline \multirow{2}{*}{ "Loma Prieta" } & $\mathrm{X}$ & 0 & 550 & 550 & beam mechanism \\
\cline { 2 - 7 } & $\mathrm{Y}$ & 0 & 550 & 550 & beam mechanism \\
\hline \multirow{2}{*}{ "Northridge-01" } & $\mathrm{X}$ & 0 & 190 & 190 & story mechanism \\
\cline { 2 - 7 } & $\mathrm{Y}$ & 0 & 190 & 190 & story mechanism \\
\hline \multirow{2}{*}{ "San Fernando" } & $\mathrm{X}$ & 0 & 400 & 400 & beam mechanism \\
\cline { 2 - 7 } & $\mathrm{Y}$ & 0 & 400 & 400 & beam mechanism \\
\hline
\end{tabular}

TABLE VIII

REVIEW OF THE YIELD MECHANISM RESULT OF R/C BUILDING STRUCTURE WITH GRADE 690MPA STEEL RE-BAR

\begin{tabular}{|c|c|c|c|c|c|}
\hline $\begin{array}{c}\text { Actual Ground Motion } \\
\text { Acceleration }\end{array}$ & $\begin{array}{c}\text { Direction } \\
\text { of Load }\end{array}$ & $\begin{array}{c}\alpha \mathrm{HTT} \\
\text { coeffisient }\end{array}$ & $\begin{array}{c}\text { Convergence } \\
\text { Total Step }\end{array}$ & $\begin{array}{c}\text { Numbers } \\
\text { of Step } \\
\text { Target }\end{array}$ & Yield Mechanism \\
\hline \multirow{2}{*}{ "Chi-Chi_Taiwan" } & $\mathrm{X}$ & -0.333 & 707 & 800 & beam mechanism \\
\cline { 2 - 6 } & $\mathrm{Y}$ & 0 & 800 & 800 & beam mechanism \\
\hline \multirow{2}{*}{ "Imperial Valley-06" } & $\mathrm{X}$ & 0 & 336 & 350 & story mechanism \\
\cline { 2 - 6 } & $\mathrm{Y}$ & 0 & 328 & 350 & beam mechanism \\
\hline \multirow{2}{*}{ "Kobe_Japan" } & $\mathrm{X}$ & -0.333 & 400 & 400 & story mechanism \\
\cline { 2 - 6 } & $\mathrm{Y}$ & 0 & 400 & 400 & beam mechanism \\
\hline \multirow{2}{*}{ "Landers" } & $\mathrm{X}$ & 0 & 900 & 900 & beam mechanism \\
\cline { 2 - 6 } & $\mathrm{Y}$ & -0.333 & 900 & 900 & beam mechanism \\
\hline \multirow{2}{*}{ "Loma Prieta" } & $\mathrm{X}$ & 0 & 384 & 550 & story mechanism \\
\cline { 2 - 6 } "Northridge-01" & $\mathrm{Y}$ & 0 & 550 & 550 & story mechanism \\
\cline { 2 - 7 } & $\mathrm{X}$ & 0 & 190 & 190 & story mechanism \\
\hline \multirow{2}{*}{ "San Fernando" } & $\mathrm{X}$ & 0 & 190 & 190 & story mechanism \\
\cline { 2 - 6 } & $\mathrm{Y}$ & 0 & 146 & 400 & story mechanism \\
\hline
\end{tabular}

TABLE IX

MAXimum Plastic Hinges Rotation of R/C BEAm ElEMENT STRUCTURE WITH GRADE 550MPA STEEL RE-BAR

\begin{tabular}{|c|c|c|c|c|c|c|}
\hline \multirow{2}{*}{$\begin{array}{l}\text { Actual Ground Motion } \\
\text { Acceleration }\end{array}$} & \multirow{2}{*}{$\begin{array}{c}\text { Direction } \\
\text { of Load }\end{array}$} & \multirow{2}{*}{$\begin{array}{l}\text { Type of } \\
\text { Beam }\end{array}$} & \multirow[t]{2}{*}{ Story } & $\begin{array}{l}\text { Moment } \\
\text { Ultimite }\end{array}$ & \begin{tabular}{|c|} 
Maximum Plastic \\
Rotation
\end{tabular} & \multirow{2}{*}{$\begin{array}{l}\text { Performance } \\
\text { Level }\end{array}$} \\
\hline & & & & $\mathrm{Nm}$ & $\mathrm{rad}$ & \\
\hline \multirow{2}{*}{ "Chi-Chi_Taiwan" } & $\mathrm{x}$ & B48-A-5 & Story5 & -461487.8 & -0.013722 & A to 10 \\
\hline & $\mathrm{Y}$ & B46-A-1 & Story6 & -230281.31 & -0.020447 & A to 10 \\
\hline \multirow{2}{*}{ "Imperial Valley-06" } & $x$ & B48-A-5 & Story5 & -465261.12 & -0.016432 & A to 10 \\
\hline & $Y$ & B46-A-2 & Story7 & -228996.2 & -0.018932 & A to 10 \\
\hline \multirow{2}{*}{ "Kobe_Japan" } & $x$ & B48-A-4 & Story4 & -478379.37 & -0.023621 & A to 10 \\
\hline & $\mathrm{Y}$ & B46-A-4 & Story5 & \begin{tabular}{|l|}
441726.3 \\
\end{tabular} & 0.027826 & LS to $C P$ \\
\hline \multirow{2}{*}{ "Landers" } & $\bar{x}$ & B48-A-5 & Story3 & -463154.87 & -0.014668 & A to 10 \\
\hline & $\mathrm{Y}$ & B46-A-2 & Story4 & -228856.86 & -0.020579 & A to 10 \\
\hline \multirow{2}{*}{ "Loma Prieta" } & $x$ & B48-A-5 & Story4 & -481700.77 & -0.025114 & A to 10 \\
\hline & $\mathrm{Y}$ & B46-A-6 & Story5 & -344192.6 & -0.029944 & 10 to LS \\
\hline \multirow{2}{*}{ "Northridge-01" } & $x$ & B48-A-4 & Story3 & -490993.48 & -0.035339 & 10 to LS \\
\hline & $Y$ & B46-A-1 & Story5 & 336504.08 & 0.038763 & LS to $C P$ \\
\hline \multirow{2}{*}{ "San Fernando" } & $x$ & B48-A-4 & Story5 & -462876.32 & -0.014534 & A to 10 \\
\hline & $Y$ & B46-A-2 & Story5 & -229057.03 & -0.019155 & A to 10 \\
\hline
\end{tabular}

TABLE X

MaXimum Plastic Hinges Rotation of R/C BEAm Element STRUCTURE WITH GRADE 690MPA STEEL RE-BAR

\begin{tabular}{|c|c|c|c|c|c|c|}
\hline \multirow{2}{*}{$\begin{array}{c}\text { Actual Ground Motion } \\
\text { Acceleration }\end{array}$} & \multirow{2}{*}{$\begin{array}{c}\text { Direction } \\
\text { of Load }\end{array}$} & \multirow{2}{*}{$\begin{array}{l}\text { Type of } \\
\text { Beam }\end{array}$} & \multirow[t]{2}{*}{ Story } & $\begin{array}{l}\text { Moment } \\
\text { Ultimite }\end{array}$ & $\begin{array}{c}\text { Maximum Plastic } \\
\text { Rotation }\end{array}$ & \multirow{2}{*}{$\begin{array}{l}\text { Performance } \\
\text { Level }\end{array}$} \\
\hline & & & & $\mathrm{Nm}$ & $\mathrm{rad}$ & \\
\hline \multirow{2}{*}{ "Chi-Chi_Taiwan" } & $x$ & B69A-A-1 & Story3 & $\begin{array}{l}-933704.5 \\
\end{array}$ & -0.011162 & A to 10 \\
\hline & $Y$ & B47-A-3 & Story5 & 840177.66 & 0.011384 & 10 to LS \\
\hline \multirow{2}{*}{ "Imperial Valley-06" } & $x$ & B69A-A-1 & Story4 & -982042.78 & -0.014867 & A to 10 \\
\hline & $\mathrm{Y}$ & B47-A-1 & Story 7 & -455502.69 & -0.015941 & A to 10 \\
\hline \multirow{2}{*}{ "Kobe_Japan" } & $x$ & B69A-A-1 & Story4 & -1003322.1 & -0.018463 & 10 to LS \\
\hline & $Y$ & B47-A-2 & Story4 & \begin{tabular}{|l|l|l}
840187.31 \\
\end{tabular} & 0.010477 & 10 to LS \\
\hline \multirow{2}{*}{ "Landers" } & $x$ & B69A-A-2 & Story5 & -905176.38 & -0.00828 & A to 10 \\
\hline & $Y$ & B47-A-1 & Story5 & -427411.37 & -0.010322 & A to 10 \\
\hline \multirow{2}{*}{ "Loma Prieta" } & $x$ & B69A-A-2 & Story4 & -1000868.5 & -0.018386 & 10 to $L S$ \\
\hline & $Y$ & B47-A-3 & Story5 & \begin{tabular}{|l|}
838906.1 \\
\end{tabular} & 0.013487 & 10 to LS \\
\hline \multirow{2}{*}{ "Northridge-01" } & $x$ & B69A-A-2 & Story4 & $\begin{array}{l}-980811.5 \\
\end{array}$ & -0.014697 & A to 10 \\
\hline & $\mathrm{Y}$ & B47-A-2 & Story5 & -450680.59 & -0.016319 & A to 10 \\
\hline \multirow{2}{*}{ "San Fernando" } & $x$ & B79A-A-3 & Story1 & -997241.01 & $\begin{array}{l}-0.11191 \\
\end{array}$ & LS to $C P$ \\
\hline & $\mathrm{Y}$ & B57-A-2 & Story3 & \begin{tabular}{|l|}
-659637.74 \\
\end{tabular} & -0.1441 & LS to $C P$ \\
\hline
\end{tabular}

The yielding mechanism of building structures with $550 \mathrm{MPa}$ strength rebar dominated by beam mechanism, while building structural collapse mechanism with $690 \mathrm{MPa}$ strength rebar dominated by story mechanism.

The maximum rotation that produces by the beam's structural elements can be used as a reference to determine the performance of the structural element.

\section{Global Performance}

1) Acceptance Criteria: The performance level of the structural system will decrease according to an increment of the displacement value which occurred at every story of the reinforced concrete building.

TABLE XI

ACCEPTANCE CRITERIA OF PERFORMANCE LEVEL ACCORDING TO STRUCTURAL DEFORMATION LIMITS (ATC-40; 1996)

\begin{tabular}{|c|c|c|c|c|}
\hline \multirow{2}{*}{$\begin{array}{c}\text { Interstory Drift } \\
\text { Limit }\end{array}$} & \multicolumn{4}{|c|}{ Performance Level } \\
\cline { 2 - 5 } & $\begin{array}{c}\text { Immediate } \\
\text { Occupancy } \\
\text { (elastis) }\end{array}$ & $\begin{array}{c}\text { Damage } \\
\text { Control }\end{array}$ & $\begin{array}{c}\text { Life } \\
\text { Safety }\end{array}$ & $\begin{array}{c}\text { Structural } \\
\text { Stability (Collapse } \\
\text { Prevention Stage) }\end{array}$ \\
\hline Max. Total Drift & 0.01 & $0.01-0.02$ & 0.02 & $0.33 \frac{V_{i}}{P_{i}}$ \\
\hline Max. Inelastic Drift & 0.005 & $0.005-0.015$ & No limit & No limit \\
\hline
\end{tabular}

TABLE XII

ACCEPTANCE CRITERIA FOR PERFORMANCE LEVEL ACCORDING TO STRUCTURAL ROOF DRIFT RATIO LIMITS (ATC-40; 1996)

\begin{tabular}{|c|c|c|c|}
\hline \multirow{3}{*}{$\begin{array}{c}\text { TOTAL DRIFT } \\
\text { RATIO }\end{array}$} & $\begin{array}{c}\text { Immidiate } \\
\text { Occupancy }\end{array}$ & Life Safety & $\begin{array}{c}\text { Collapse } \\
\text { Prevention }\end{array}$ \\
\cline { 2 - 4 } & 0.005 & 0.01 & 0.02 \\
\hline
\end{tabular}


The parameter that can be used to provide performance level measurement of a structural building system is calculated by a drift ratio as an effect of seismic load design. There are two kinds of drift ratio value to be concerned in the global measurement of the reinforced concrete building performance level which is: maximum total drift and roof drift ratio.

The average result of the drift ratio caused by the seven pairs of actual ground motion acceleration is used as a reference to determine the global performance of building system structure. Because of that, performance level that is generated through global performance analysis can represent the performance level system structure.

2) Interstory Drift Ratio: From the result of the average interstory drift ratio analysis that has been done, the level global performance for both building structure with $550 \mathrm{MPa}$ and $690 \mathrm{MPa}$ strength rebar is still in the limit of interstory drift ratio IO to LS (Damage Control).
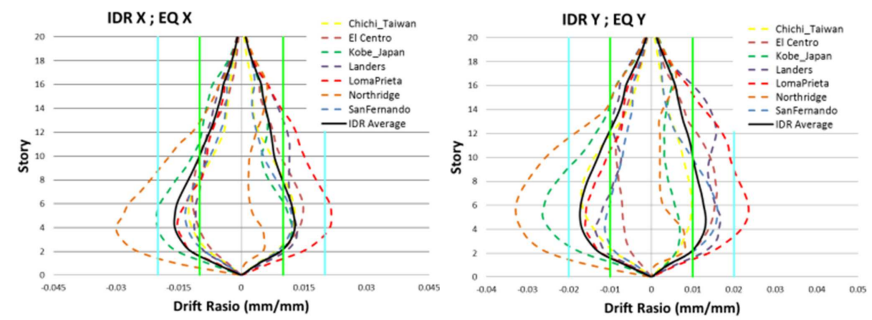

Fig. 24 The average of interstory drift ratio from R/C building structure with grade $550 \mathrm{MPa}$ steel re-bar caused by the seismic load at $\mathrm{X}$ and $\mathrm{Y}$ direction
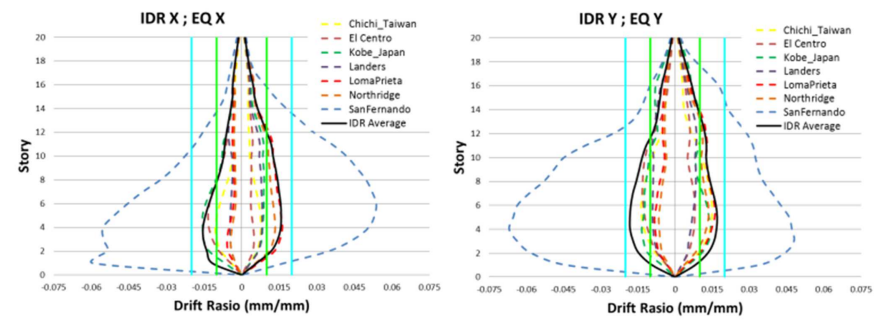

Fig. 25 The average of interstory drift ratio from R/C building structure with grade $690 \mathrm{MPa}$ steel re-bar caused by the seismic load at X and Y direction

The biggest interstory drift ratio which occurred in the building structure with $550 \mathrm{MPa}$ and $690 \mathrm{MPa}$ strength rebars are as follows: 0.01729 and 0.0182 , it almost exceeds the interstory drift ratio life safety limit (0.02).

Both are produced as an effect of actual ground motion acceleration seismic load towards $\mathrm{Y}$ with deformation movement through negative $\mathrm{Y}$ global axis of the building structure.

3) Roof Drift Ratio: The deviation value that issues for the analysis is the biggest displacement value that occurred at the center of mass roof story level as a result of the seismic distribution base shear load on the story which produces through a variety of structural mode shape natural period response as long as the actual ground motion acceleration seismic load occurs.
TABLE XIII

Global PERFormance LEVEl ACCORDING TO RoOF DRIFT RATIO OF R/C BUILDING STRUCTURE WITH GRADE 550MPA STEEL RE-BAR CAUSED BY ACTUAL GROUND MOTION ACCELERATION TOWARD X AND Y AXIS

\begin{tabular}{|c|c|c|c|c|}
\hline \multirow{3}{*}{$\begin{array}{l}\text { Ground Motion } \\
\text { Acceleration }\end{array}$} & \multicolumn{4}{|c|}{ Roof Drift Ratio (RDR) } \\
\hline & \multicolumn{2}{|c|}{ UX } & \multicolumn{2}{|c|}{ UY } \\
\hline & MAX & MIN & MAX & MIN \\
\hline "Chi-Chi_Taiwan" & 0.00582 & -0.00568 & 0.00526 & -0.00863 \\
\hline "Imperial Valley-06" & 0.00715 & -0.00566 & 0.00838 & -0.00374 \\
\hline "Kobe_Japan" & 0.00455 & -0.00827 & 0.00193 & -0.01156 \\
\hline "Landers" & 0.00799 & -0.00510 & 0.00955 & -0.00532 \\
\hline "Loma Prieta" & 0.01137 & -0.00578 & 0.01284 & -0.00687 \\
\hline "Northridge-01" & 0.00132 & -0.01147 & 0.00135 & -0.01708 \\
\hline "San Fernando" & 0.00526 & -0.00608 & 0.00724 & -0.00579 \\
\hline Average & 0.00621 & -0.00686 & 0.00665 & -0.00843 \\
\hline Global Performance & 10 & 10 & 10 & 10 \\
\hline
\end{tabular}

TABLE XIV

Global PERFormance LEVEl ACCORDING TO Roof DRIFT RATIO OF R/C BUILDING STRUCTURE WITH GRADE 550MPA STEEL RE-BAR CAUSED BY ACTUAL GRound Motion ACCELERATION TOWARD X AND Y AXIS

\begin{tabular}{|c|c|c|c|c|}
\hline \multirow{2}{*}{$\begin{array}{c}\text { Ground Motion } \\
\text { Acceleration }\end{array}$} & \multicolumn{4}{|c|}{ Roof Drift Ratio (RDR) } \\
\cline { 2 - 5 } & \multicolumn{2}{|c|}{ UX } & \multicolumn{2}{c|}{ UY } \\
\cline { 2 - 5 } & MAX & MIN & MAX & MIN \\
\hline "Chi-Chi_Taiwan" & 0.00375 & -0.00430 & 0.00739 & -0.00640 \\
\hline "Imperial Valley-06" & 0.00298 & -0.00627 & 0.00438 & -0.00661 \\
\hline "Kobe_Japan" & 0.00534 & -0.00674 & 0.00638 & -0.00635 \\
\hline "Landers" & 0.00488 & -0.00308 & 0.00484 & -0.00533 \\
\hline "Loma Prieta" & 0.00849 & -0.00250 & 0.00771 & -0.00308 \\
\hline "Northridge-01" & 0.00727 & -0.00206 & 0.00665 & -0.00243 \\
\hline "San Fernando" & 0.02702 & -0.02210 & 0.02143 & -0.02726 \\
\hline \multirow{4}{*}{ Average } & 0.00853 & -0.00672 & 0.00840 & -0.00821 \\
\cline { 2 - 6 } Global Performance & 10 & 10 & 10 & 10 \\
\cline { 2 - 5 } &
\end{tabular}

From the average roof drift ratio analysis result that has been done, the level global performance for both reinforcement concrete building structure with $550 \mathrm{MPa}$ and 690MPa strength rebars are still within the limit of roof drift ratio IO to LS (Damage Control).

The biggest roof drift ratio that occurs in the building structure with grade $550 \mathrm{MPa}$ is 0.00843 caused by actual ground motion acceleration towards $\mathrm{Y}$ direction with deformation movement to the global axis of negative $\mathrm{Y}$ from the building structure. The biggest roof drift ratio that occurs in the building structure with grade $690 \mathrm{MPa}$ is 0.0084 caused by actual ground motion acceleration towards $\mathrm{Y}$ direction with deformation movement to the global axis of positive $\mathrm{Y}$ from the building structure.

\section{CONCLUSIONS}

From the result of literature studies and performance analysis that is done related to seismic performances $550 \mathrm{MPa}$ and $690 \mathrm{MPa}$ high strength rebar in r/c building, we can conclude important things, which are: Preliminary the section dimension of $\mathrm{r} / \mathrm{c}$ element structure produce bigger size than preliminary using normal rebar strength, both for $\mathrm{r} / \mathrm{c}$ beam and column. The parameter of plastic hinges moment-rotation relationship curve and acceptance criteria of high-strength $\mathrm{r} / \mathrm{c}$ element performance has to be determined through moment-curvature analysis of the section independently. The mechanism of the building structure collapse with grade $550 \mathrm{MPa}$ is dominated by beam mechanism. But for the mechanism of the building structure collapse with grade $690 \mathrm{MPa}$ is dominated by story 
mechanism. Global performance of high rise r/c building with grade $550 \mathrm{MPa}$ and $690 \mathrm{MPa}$ is in the level of performance damage control. The concentration of energy dissipation of biggest seismic load by the r/c beam happens in $4^{\text {th }}$ and $5^{\text {th }}$ floor, both in high rise r/c building with grade $550 \mathrm{MPa}$ and $690 \mathrm{MPa}$. The material of high strength rebar can be used in special moment frame r/c building design if supported by the result of experiment data and accounted structure analysis.

\section{ACKNOWLEDGEMENTS}

The writer would like to acknowledge Prof. Ir. Iswandi Imran, MAS.c., Ph.D. as thesis advisor whom in his patience has given support and guidance so that this study can be accomplished well. I would like to thank PENTA REKAYASA Company which allows the writer to use ETABS 2016 v.16.0.2 licensed for the company so that the result of the analysis is accountable.

\section{REFERENCES}

[1] Iswandi Imran dan Fajar Hendrik, "Perencanaan Lanjut Struktur Beton Bertulang”, Bandung Institute of Technology, Bandung, West Java, 2014.

[2] Charles Pankow Foundation, "Determination of Yield Strength for Nonprestressed Steel Reinforcement", Final Report RGA 04-13, Wiss, Janney, Elstner Associates, Inc. South Lake Avenue, 2013.

[3] Constructed Facilities Laboratory, "A706 Grade 80 Reinforcement for Seismic Application”, Research Report No. RD-15-15, Department of Civil, Construction, and Environmental Engineering, North California State University.

[4] Applied Technology Council, "Roadmap for The Use of HighStrength Reinforcement in Reinfoced Concrete Design”, ATC-115, Redwood City, California, 2014.

[5] National Institute of Standards and Technology, "Use of HighStrength Reinforcement in Earthquake-Resistant Concrete Structures", NIST GCR 14-917-30, America, 2014.

[6] H. Aoyama, "Design of Modern Highrise Reinforced Concrete Structure”, Vol 3, University of Tokyo, Japan, 2001.

[7] H. Tavallali, "Cyclic Response of Concrete Beams Reinforced with Ultrahigh Strength Steel", Ph. D. Thesis. Pennsylvania State University, Pennsylvania, 2011.

[8] American Concrete Institute, "Design Guide for The Use of ASTM A1035/A1035M Grade 100 (690) Steel Bars for Structural Concrete”, America, ACI ITG-6R-10, 2010.
[9] American Concrete Institute, "Building Code Requirements for Structural Concrete," ACI 318-14, America, 2014.

[10] American Society for Testing and Materials, "Standard Specification for Deformed and Plain Low-Alloy Steel Bars for Concrete Reinforcement", ASTM A706/A706-14, America, 2014.

[11] American Society for Testing and Materials, "Deformed and Plain Carbon-Steel Bars for Concrete Reinforcement", ASTM A615/A615M-15, America, 2015.

[12] American Society for Testing and Materials, "Deformed and Plain, Low-Carbon, Chromium, Steel Bars for Concrete Reinforcement", ASTM A1035/A1035M-14, America, 2014.

[13] T.Paulay and M.J.N. Priestley, "Seismic Design of Reinforced Concrete and Mansory Buildings", John Wiley \& Sons, Inc., San Diego, 1991.

[14] National Cooperative Highway Research Program, "Design of Concrete Structures Using High-Strength Steel Reinforcement", NCHRP Report 679, Washington, 2011.

[15] National Institute of Standards and Technology, "Seismic Design of Reinforced Concrete Special Moment Frame", NEHRP Seismic Design Technical Brief No.1, Second Edition, America. 2016.

[16] ICC Evaluation Sevice Report, "SAS Stress Steel Grade 97 Thread Bar Steel Reinforcing Bars and Couplers", ESR-1163, New Jersey, 2016.

[17] B. E. Drit Sokoli, "Seismic Performance of Concrete Column Reinforced with High Strength Steel", Thesis, The University of Texas, 2014.

[18] American Society of Civil Engineers, "Seismic Evaluation and Retrofit of Existing Buildings", ASCE/SEI 41-13, Virginia, 2013.

[19] American Society of Civil Engineers, "Minimum Design Loads for Buildings and Other Structures", ASCE/SEI 7-10, Virginia, 2010.

[20] R. Park and T. Paulay, "Reinforced Concrete Structures", Department of Civil Engineering, University of Christchurch, New Zealand, 1975.

[21] Finley A. Charney, Ph.D., P.E, "Seismic Load : Guide to The Provision of ASCE 7-10", American Society of Civil Engineers, Virginia, 2010.

[22] Standar Nasional Indonesia, "Persyaratan Beton Struktural untuk Bangunan Gedung”, SNI 2847:2013, Jakarta, 2013.

[23] Standar Nasional Indonesia, "Tata Cara Perencanaan Ketahanan Gempa untuk Struktur Bangunan Gedung dan Non Gedung", SNI 1726:2012, Jakarta, 2012.

[24] Standar Nasional Indonesia, "Beban Minimum untuk Perancangan Bangungan Gedung dan Struktur Lain”, SNI 1727:2013, Jakarta, 2013.

[25] Earthquake Engineering Research Institute, "Practical Guidelines to Select and Scale Earthquake Records for Nonlinear Response History Analysis of Structure", USGS File Report, Amerika, 2010. 